\title{
Population structure, condition and diet of Oligosarcus paranensis (Menezes \& Gery, 1983) (Osteichthyes: Characidae) at two reservoirs in South Brazil
}

\author{
Milza Celi Fedatto Abelha ${ }^{1,4}$, Elaine Antoniassi Luiz Kashiwaqui ${ }^{1,2}$ \& Erivelto Goulart $^{3}$ \\ Grupo de Estudos em Ciências Ambientais e Educação - GEAMBE, \\ Universidade Estadual de Mato Grosso do Sul - UEMS, BR 163, Km 20.2, \\ Bairro Universitário, CEP 79980-000, Mundo Novo, MS, Brasil. www.uems.br \\ ${ }^{2}$ Grupo de Pesquisa em Tecnologia de Produção e Conservação de Recursos Pesqueiros e Hídricos- \\ GETECH, Universidade Estadual do Oeste do Paraná - UNIOESTE, \\ Rua da Faculdade, 645, Jardim Santa Maria, CEP 85903-000, Toledo, PR, Brasil. www.unioeste.br \\ ${ }^{3}$ Programa de Pós-graduação em Ecologia de Ambientes Aquáticos Continentais - PEA, \\ Núcleo de Pesquisas em Limnologia e Aquicultura - NUPÉLIA, \\ Universidade Estadual de Maringá - UEM, Av. Colombo, 5970, Bloco G90, \\ CEP 87020-900, Maringá, PR, Brasil.www.uem.br \\ ${ }^{4}$ Corresponding author: Milza Celi Fedatto Abelha, e-mail: mcfabelha@gmail.com
}

ABELHA, M.C.F., KASHIWAQUI, E.A.L. \& GOULART, E. Population structure, condition and diet of Oligosarcus paranensis (Menezes \& Gery, 1983) (Osteichthyes: Characidae) at two reservoirs in South Brazil. Biota Neotrop. 12(1): http://www.biotaneotropica.org.br/v12n1/en/abstract?article+bn02112012012.

\begin{abstract}
This study investigated the population parameters, condition and diet of Oligosarcus paranensis at Fiú and Mourão Reservoirs, located in Paraná State, Brazil. The fishes were collected quarterly between 1996/1997 and 1998/1999 using gillnets. Food items were quantified by volumetric method. The specimens at Fiú showed comparatively smaller length and worse condition. Sex ratio was statistically equal to 1:1 at Mourão, whereas there was a significant predominance of males at Fiú. Sex ratio also varied among size classes. Allometric growth prevailed among the studied groups. The diet consisted mainly of fishes and was complemented with invertebrates and plant matter in both reservoirs. There was a change in the feeding pattern as the standard length increased. Fishes changed from invertivores to piscivores, except for males in Mourão, for which a reverse trend occurred. Keywords: fish, sex ratio, feeding, dog-tooth characid, impoundments.
\end{abstract}

ABELHA, M.C.F., KASHIWAQUI, E.A.L. \& GOULART, E. Estrutura populacional, condição e dieta de Oligosarcus paranensis (Menezes \& Gery, 1983) (Osteichthyes: Characidae) em dois reservatórios do sul do Brasil. Biota Neotrop. 12(1): http://www.biotaneotropica.org.br/v12n1/pt/abstract?article+bn02112012012.

Resumo: Este estudo investigou parâmetros populacionais, a condição e a dieta de Oligosarcus paranensis nos reservatórios de Fiú e Mourão, localizados no Estado do Paraná, Brasil. As coletas foram trimestrais, entre 1996/1997 e 1998/1999 utilizando-se redes de espera. Os itens alimentares foram quantificados pelo método volumétrico. Os espécimes de Fiú apresentaram, comparativamente, menor comprimento e pior condição. A proporção sexual foi estatisticamente igual a 1:1 em Mourão, enquanto que os machos prevaleceram de forma significativa em Fiú. A proporção sexual variou ainda entre as classes de comprimento, com os machos predominando nas classes inferiores e as fêmeas nas superiores em ambos os reservatórios. O crescimento alométrico prevaleceu entre os grupos estudados, com exceção dos machos em Fiú, os quais apresentaram crescimento isométrico. A dieta foi composta principalmente por peixes e complementada com invertebrados e vegetais em ambos os reservatórios. Houve mudança no padrão alimentar com o aumento do comprimento padrão. Os peixes passaram de invertívoros para piscívoros, excetuando-se os machos em Mourão, com os quais ocorreu tendência contrária.

Palavras-chave: peixe, razão sexual, alimentação, peixe-cachorro, barramentos. 


\section{Introduction}

The geographic distribution of the characid Oligosarcus is restricted to South America, with seventeen recognized species (Menezes \& Ribeiro 2010). They inhabit the headwaters of Andean rivers in Bolivia and Argentina, north of Uruguay and Brazilian territory, where Oligosarcus paranensis is popularly known as 'peixe-cachorro' and is widely distributed in the Upper Paraná River floodplain (Menezes 1988).

Natural habitats with recorded Oligosarcus species include low order streams (Teixeira 1989, Castro \& Casatti 1997, Vono et al.1997, Deus \& Petrere Junior 2003) and lagoons, including coastal lagoons (Hartz et al. 1996, Nunes \& Hartz 2006, Garcia et al. 2007) and floodplain lagoons (Meschiatti 1995, Sosnovsky \& Quirós 2009).

Oligosarcus has also been recorded in reservoirs (Castro 1996, Gealh \& Hahn 1998, Araújo et al. 2005, Luz-Agostinho et al. 2006, Terra \& Araújo 2011), and, in the specific case of $O$. paranensis, ichthyofaunal suveys have reported its occurrence in the Atibainha, Cachoeira, Taiaçupeba and Itupararanga Reservoirs in the State of São Paulo (Castro \& Arcifa 1987, Smith \& Petrere Junior 2008) and at Fiú, Mourão, Capivari and Rio dos Patos Reservoirs in the State of Paraná (Luiz et al. 2003). The abundance of this species varied among those ecosystems; however, at Fiú and Mourão, O. paranensis stood out during captures (the most and the second most abundant species, respectively). High population abundance is one of the indicators of fish species adaptability to damming, which promotes impacts, such as replacement of the lotic environment by a lentic one, obstruction of migratory activities, progressive loss of environmental heterogeneity and instability of the shoreline as a result of sudden oscillations in water level (Agostinho et al. 1999). Particularly in Brazil, hydroelectric reservoirs are frequent components of the landscape. Even though $O$. paranensis figures among the most successful species to colonize this type of environment (Smith \& Petrere Junior 2008), its population attributes and trophic ecology are still scarcely known.

The quantification of population parameters such as sex ratio, length distribution, growth type and condition, as well as diet and feeding behavior evaluation, provide valuable information for the understanding of species ecology, as they reflect the prevailing environmental conditions. However, females and males can respond differently to environmental conditions, and variations in population parameters can also be found between the sexes within a single population (Vazzoler 1996, Pope \& Kruse 2007). Wootton (1999) emphasized the variability of these parameters for the same species in different environments, and attributed this fact to the flexible nature of growth (length and weight) in fish and its correlation with the energy and nutrients provided by feeding activity. In the reservoirs here studied, significant differences were detected in abiotic parameters and between fish fauna structure (Luiz et al. 2003) indicating that distinct selective forces might being guiding fish species abundance. In spite of that, the reservoirs are similar in the fact of having $O$. paranensis among the dominant species. Such considerations gave rise to the following question: does $O$. paranensis show similar populations parameters, condition and diet in Fiú and Mourão Reservoirs?

Therefore, in order to contribute to the knowledge on the ecology of $O$. paranensis present in hydroelectric reservoirs, the objective of this study was to describe and compare its population parameters, condition and diet composition between the populations and among different length classes of both sexes at the Fiú and Mourão Reservoirs, Paraná State, Brazil.

\section{Material and Methods}

\section{Study area}

The present study involved the Fiú $\left(23^{\circ} 44^{\prime} 56,2^{\prime \prime} \mathrm{S}\right.$ and

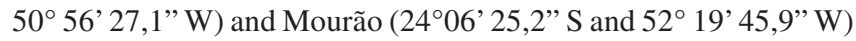
hydroelectric reservoirs, located in Paraná State, Brazil (Figure 1; Table 1), in areas where the economy is based on farming and cattle raising. This anthropogenic use of the environment has resulted, for both reservoirs, in a surrounding area consisting predominantly of pastures and banks occupied by structurally simplified riparian vegetation, dominated by grasses. The reservoirs also have in common the fact that they are old, small, resulting from the damming of low order streams (Júlio Junior et al. 2005; Table 1), oligotrophic, without oxygenation restrictions along the water column (Pagioro et al. 2005), and practically devoid of environmental structure given by aquatic macrophytes, which were seldom observed in both ecosystems.

\section{Sampling}

The collections were made at quarterly intervals in the period from May/1996 to February/1997 and May/1998 to August/1999 at Fiú; from May/1996 to February/1997 and May/1998 to February/1998 at Mourão. Specimens were collected using 14 gillnets: 11 of them simple nets (mesh sizes $2.4 ; 3.0 ; 4.0 ; 5.0 ; 6.0 ; 7.0 ; 8.0 ; 10.0 ; 12.0 ; 14.0$ and $16.0 \mathrm{~cm}$, measured between opposite nodes) and three trammel nets (internal mesh sizes 6.0; 7.0 and $8.0 \mathrm{~cm}$ between opposite nodes). Fishing gears were set for 24 hours in the main body of the reservoirs, with harvests in the morning ( 8 hours), afternoon (16 hours) and evening ( 22 hours). Specimens were fixed in $10 \%$ formaldehyde and taken to the laboratories of the Núcleo de Pesquisa em Limnologia, Ictiologia e Aquicultura (Nupélia) at the Universidade Estadual de Maringá, Brazil, where they were identified and eviscerated. Each exemplar was measured for length (total and standard; $\mathrm{cm}$ ), total weight $(\mathrm{g})$, gonad weight $(\mathrm{g})$, and stages of gonadal development. Voucher specimens were deposited in the Ichthyological Collection of Nupélia, Universidade Estadual de Maringá, found in: http://peixe. nupelia.uem.br/.

\section{Data analysis}

In the analysis of population structure, the female and male ratios were established by standard length class (1.0 cm intervals) and for total sampled specimens. Differences in the sex ratio were evaluated using the chi-square $\left(\chi^{2}\right)$ test. In tables and figures considering the standard length classes, the notation "(-]" indicates an interval closed to the left (parentheses) and open to the right (bracket).

The analysis of covariance (ANCOVA) (García-Berthou 2001, Pope \& Kruse 2007) and the Separate Slope Model (SSM) were applied to test for possible differences (including the pos hoc Modified Tukey test for Unequal NHSD) in the condition between $O$. paranensis populations as well as among the standard length classes of females and males with numerical representation (20 or more specimens) in both reservoirs. The assumptions of the ANCOVA were tested and the Separate Slope Model was used in the cases in which the data did not meet the assumption of homogeneity of slopes (a test to assess differences in slopes of two or more lines, with the null hypothesis that the regression coefficients are equal; Pope \& Kruse 2007). In ANCOVA the length was considered as covariate.

These statistical procedures were applied to the values resulting from the linearization of the weight-length relationship expression $\mathrm{TW}=a \mathrm{SL}^{b}$, through its natural logarithm: $\ln \mathrm{TW}=\ln a+b \operatorname{lnSL}$, in which TW is the total weight in grams, SL is the standard length in 


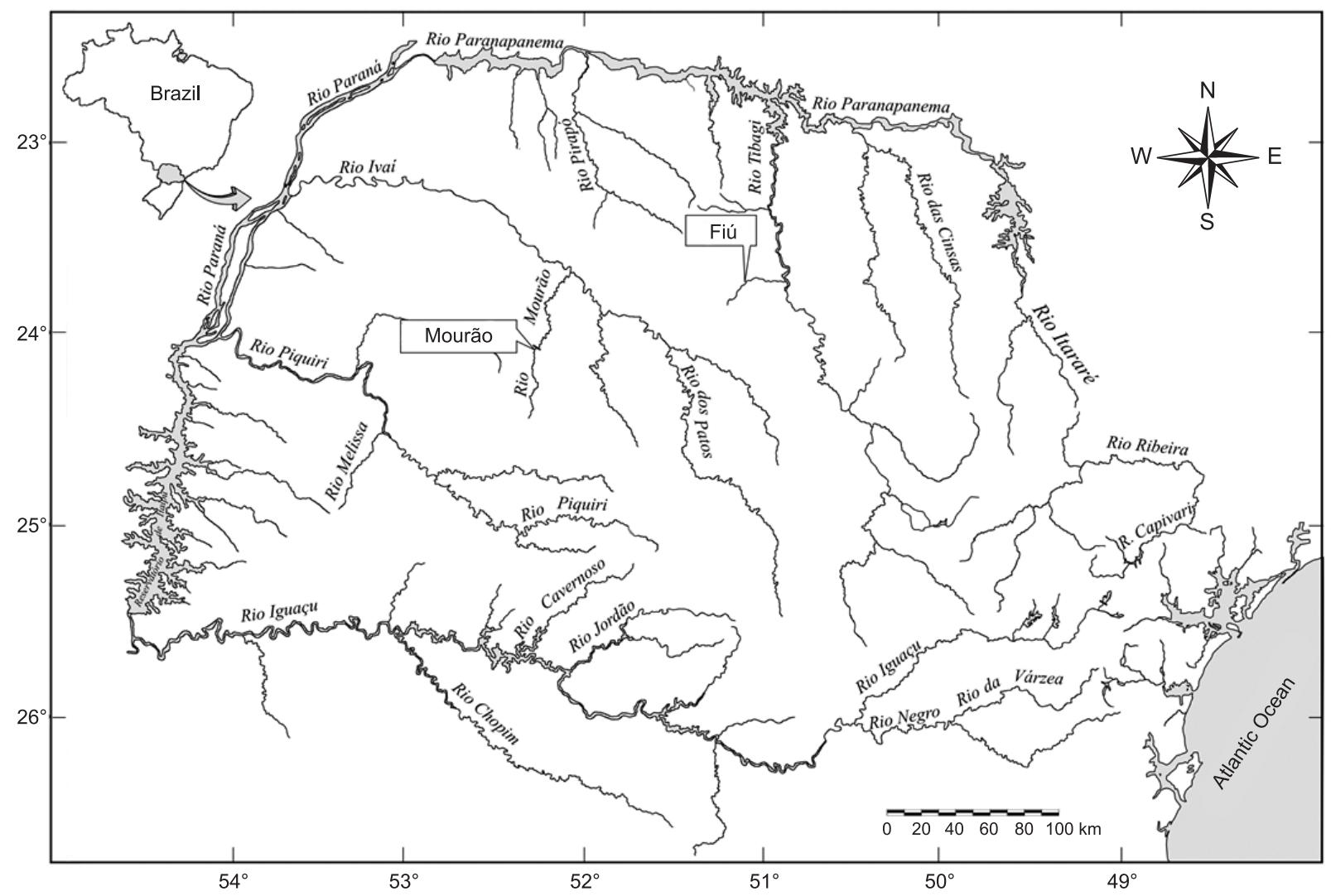

Figure 1. Location of Fiú and Mourão Reservoirs at Paraná State, Brazil.

Figura 1. Localização dos reservatórios Fiú e Mourão no estado do Paraná, Brasil.

Table 1. General characteristics of Fiú and Mourão Reservoirs, Parana State, Brazil (Abelha, 2001).

Tabela 1. Características gerais dos reservatórios Fiú e Mourão, estado do Paraná, Brasil (Abelha, 2001).

\begin{tabular}{lll}
\hline \multicolumn{1}{c}{ Reservoir } & \multicolumn{1}{c}{ Fiú } & \multicolumn{1}{c}{ Mourão } \\
\hline River & Apucaraninha & Mourão \\
Basin & Tibagi & Ivaí \\
City & Tamarana & Campo Mourão \\
Dam's closure year & 1958 & 1964 \\
Area $\left(\mathrm{km}^{2}\right)$ & 1.7 & 10.5 \\
Mean transparency in the & 0.57 & 1.07 \\
sampling period $(\mathrm{m})$ & & \\
\hline
\end{tabular}

centimeters, $a$ is the intercept, and $b$ is the regression coefficient (Pope $\&$ Kruse 2007). The latter also provides information on the type of growth of the specimens. The growing is considered isometric if the fish retain the same shape as it grows and, in this case, $b$ takes de value 3.0; on the other hand, a $b$ value significantly different from 3.0 indicates allometric growth (Wootton 1999, Pope \& Kruse 2007). The $t$ test was applied on the $b$ values obtained for both sexes in the studied populations, in order to evaluate the null hypothesis that $b=3.0$. The linear regressions and statistical analyses were computed by the program Statistica ${ }^{\mathrm{TM}}$ (StatSoft 2005). The significance level used in all statistical tests was $\alpha=0.05$.
Stomachs contents were analyzed in accordance with the volumetric method (volume percentage of each item in relation to the total volume of stomach contents; Hyslop 1980) and the contribution of food items in the diet was expressed in percentage of volume $(\% \mathrm{~V})$. The volume of each food item was determined using graduated test tubes and a counting chamber for small items $(<1.0 \mathrm{~mL})$ (Hellawell \& Abel 1971) with the result converted into milliliters. Food items were identified down to the lowest possible taxonomic level. However, for comparative analyses between the reservoirs, the items were grouped into four broad food resources, named plant matter, invertebrates, fish, and others. The description of items belonging to each resource is shown on Table 5 .

\section{Results}

In the study, 1,639 specimens (642 females; 997 males) of O. paranensis were captured at Fiú, and 5,034 (2,452 females; 2,582 males) at Mourão. A total of 122 stomachs contents were analyzed for Fiú and 200 for Mourão. From all the captured specimens in each reservoir, less than $4 \%$ (Fiú $=3.0 \%$ and Mourão $=3.9 \%$ ) showed immature gonads. Therefore, the described results comprise mainly the adult stratum of the studied populations.

The minimum and maximum standard length values for males and females were, respectively, $6.20-13.50 \mathrm{~cm}$ and $6.50-16.90 \mathrm{~cm}$ at Fiú and $6.40-15.30 \mathrm{~cm}$ and $6.70-19.70 \mathrm{~cm}$ at Mourão. The relative frequency distribution of specimens by standard length class (Figure 2) indicated that, for total population, fishes measuring 

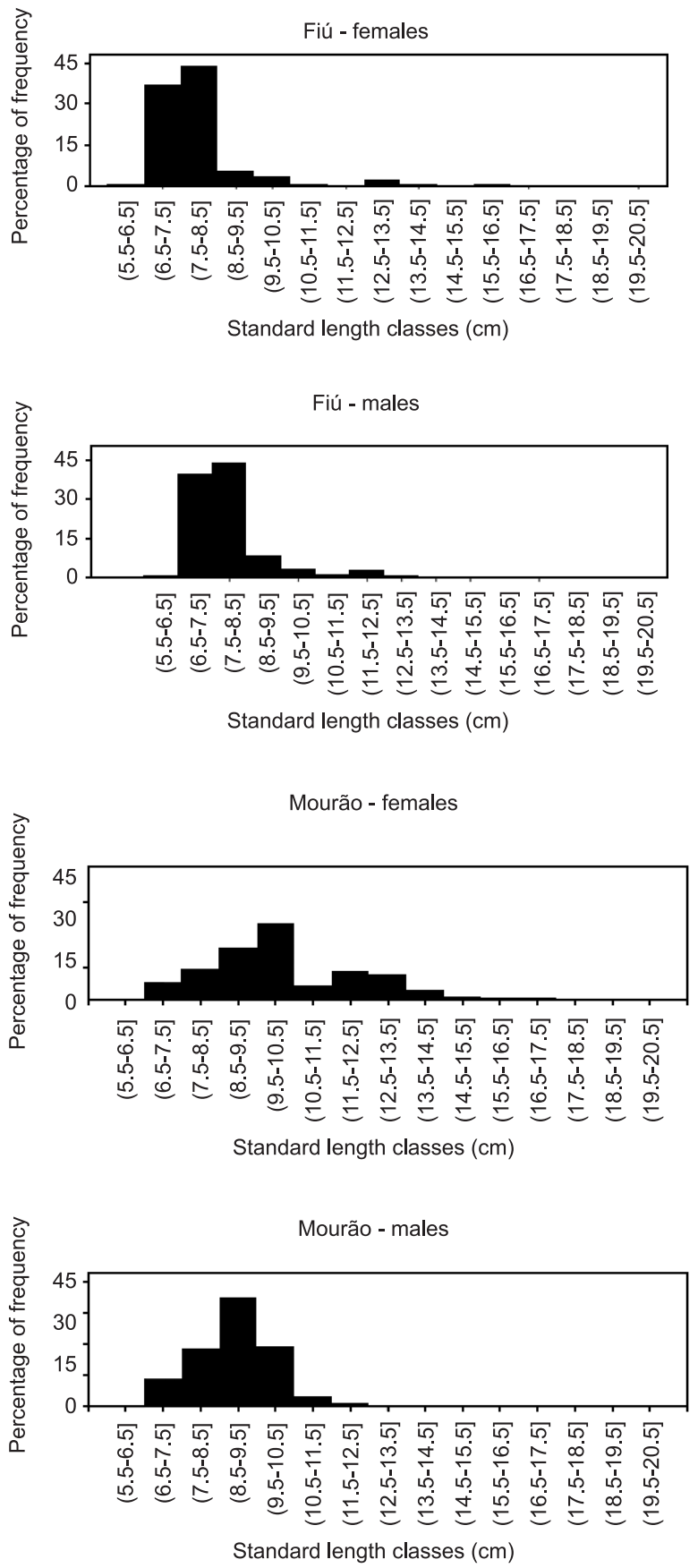

Figure 2. Numeric relative frequency of Oligosarcus paranensis females and males per $1.0 \mathrm{~cm}$ standard length size classes at Fiú and Mourão Reservoirs, Paraná State, Brazil.

Figura 2. Frequência numérica relativa de fêmeas e machos de Oligosarcus paranensis em classes de tamanho padrão de $1.0 \mathrm{~cm}$ nos reservatórios de Fiú e Mourão, estado do Paraná, Brasil.

between $6.50-8.50 \mathrm{~cm}$ and $8.50-10.50 \mathrm{~cm}$ were, respectively, caught more frequently at Fiú and Mourão. Males and females were greater in Mourão.

The results of the chi-square $\left(\chi^{2}\right)$ test applied on the differences in sex ratios are presented on Table 2 . Considering the total specimens captured at each reservoir, it was verified that in Mourão, the population was distributed equitably between the sexes, whereas in Fiú, males were significantly predominant (1.6:1.0). However, the analysis of sex ratio by standard length class showed the significant predominance of males in the shorter length classes and of females in the higher classes was common to both reservoirs. Statistically similar sex ratios occurred in only one length class in Fiú (12.50-13.50] and other in Mourão (9.50-10.50].

The results of the ln-transformated weight-length relationship of females and males are shown on Table 3. Figure 3 shows the adjusted lines to the empirical points of that relationship.

The values of $b$ were significantly different than 3.0 for both sexes at Mourão (females: $t_{(\mathrm{df}=2453)}=2.85, \mathrm{p}<0.05$; males: $t_{(\mathrm{df}=2581)}=3.11$, $\mathrm{p}<0.05)$ and for females at Fiú $\left(t_{(\mathrm{df}=641)}=5.72, \mathrm{p}<0.05\right)$, which characterizes allometric growth. On the other hand, $b$ was statistically equal to $3.0\left(t_{(\mathrm{df}=996)}=0.03, \mathrm{p}>0.05\right)$ for males at Fiú, indicating isometric growth.

For the condition evaluation, the ANCOVA assumptions were met, except for the one regarding the slopes homogeneity, which was valid for part of the evaluated factors (Table 4). The ANCOVA and SSM showed significant differences in condition between the populations of two reservoirs and among the standard length classes for both sexes, with the single exception of the statistically similar condition for males with standard length between 9.50 and $10.50 \mathrm{~cm}$ (Table 4). In all cases with detected differences, the results of the pos hoc test (Modificated Tukey test for Unequal NHSD) showed a significantly better condition $(\mathrm{p}<0.01)$ of the specimens at Mourão. It is worth mentioning that the standard length classes evaluated in this analysis included those that were most abundant in both reservoirs.

In spite of the taxa diversity of the invertebrates consumed, fishes were the most representative food resource $(\% \mathrm{~V}>60)$ in the diet of O. paranensis at both sexes and reservoirs (Table 5). Small characids (part of them were Astyanax spp. and Bryconamericus iheringi) prevailed as prey for both sexes at Fiú, while at Mourão, cichlids were consumed predominantly by females and characids by males. There was also evidence of cannibalism at Fiú. Furthermore, it was detected predation on exotics species such as Tilapia rendalli and Micropterus salmoides at Mourão. Piscivory intensity varied between the sexes, being more expressive among the females at Fiú $(\% \mathrm{~V}$ fishes $=96.91)$ and less evident for the same sex at Mourão, where fruits/seeds and invertebrates (aquatic and terrestrial) reached $36.68 \%$ of total diet volume. Invertebrates were also representative in feeding supplementation for Mourão males $(\% \mathrm{~V}$ invertebrates $=18.42)$ and those at Fiú $(\%$ V invertebrates $=17.66)$. These results characterized the predominantly piscivorous feeding habit of the species for both reservoirs.

The diet analysis performed in the standard length classes (Figures 4-5) revealed that for Fiú there was a modification of the feeding habit from invertivorous to piscivorous with the increase in standard length for both sexes (for females, there were no stomachs for the 10.5-11.5 cm class and no captured specimens for the 11.5-12.5 cm). This trend was also observed among the females at Mourão. Conversely, among the males at the latter reservoir, invertebrates' intake intensified with the increase in specimen length. The smallest $(5.5-6.5 \mathrm{~cm})$ and the largest captured fishes $(19.5-20.5 \mathrm{~cm})$ showed empty stomachs, therefore, they were not included in the diet analysis.

\section{Discussion}

In fish, a complex set of selective forces (from abiotic environment and biotic interactions) determines the amount of 
Table 2. Distribution of females and males per standard length class and results of the chi-square $\left(\chi^{2}\right)$ test applied to the sex ratio of Oligosarcus paranensis at Fiú and Mourão Reservoirs, Paraná State, Brazil. $n=$ number of specimens; $\%=$ frequency; $*=5 \%$ level of significance.

Tabela 2. Distribuição de fêmeas e machos por classe de comprimento padrão e resultado do teste de chi-quadrado $\left(\chi^{2}\right)$ aplicado sobre a razão sexual de Oligosarcus paranensis nos reservatórios de Fiú e Mourão, estado do Paraná, Brasil. n = número de indivíduos; \% = frequência; * = nível de significância de 5\%.

\begin{tabular}{|c|c|c|c|c|c|c|c|c|c|c|}
\hline \multirow{4}{*}{$\begin{array}{l}\text { Length } \\
\text { class }(\mathrm{cm})\end{array}$} & \multicolumn{10}{|c|}{ Reservoirs } \\
\hline & \multicolumn{5}{|c|}{ Fiú } & \multicolumn{5}{|c|}{ Mourão } \\
\hline & \multicolumn{2}{|c|}{$\mathbf{F}$} & \multicolumn{2}{|c|}{$\mathbf{M}$} & \multirow[t]{2}{*}{$\chi^{2}$} & \multicolumn{2}{|c|}{$\mathbf{F}$} & \multicolumn{2}{|c|}{ M } & \multirow[t]{2}{*}{$\chi^{2}$} \\
\hline & $\mathbf{n}$ & $\%$ & $\mathbf{n}$ & $\%$ & & $\mathbf{n}$ & $\%$ & $\mathbf{n}$ & $\%$ & \\
\hline$(5.50-6.50]$ & - & 0.00 & 2 & 100.00 & $100.00 *$ & - & 0.00 & 1 & 100.00 & $100.00 *$ \\
\hline$(6.50-7.50]$ & 172 & 38.31 & 277 & 61.69 & $5.47 *$ & 111 & 35.81 & 199 & 64.19 & $8.06 *$ \\
\hline$(7.50-8.50]$ & 364 & 39.91 & 548 & 60.09 & $4.07 *$ & 304 & 35.39 & 555 & 64.61 & $8.54 *$ \\
\hline$(8.50-9.50]$ & 39 & 32.23 & 82 & 67.77 & $12.63^{*}$ & 382 & 29.12 & 930 & 70.88 & $17.45^{*}$ \\
\hline$(9.50-10.50]$ & 28 & 38.89 & 44 & 61.11 & $4.94 *$ & 767 & 50.96 & 738 & 49.04 & 0.04 \\
\hline$(10.50-11.50]$ & 7 & 50.00 & 7 & 50.00 & $0.00 *$ & 195 & 63.31 & 113 & 36.69 & $7.09 *$ \\
\hline$(11.50-12.50]$ & - & 0 & 27 & 100 & $100.00 *$ & 224 & 87.16 & 33 & 12.84 & $55.23 *$ \\
\hline$(12.50-13.50]$ & 13 & 59.09 & 9 & 40.91 & 3.31 & 258 & 97.36 & 7 & 2.64 & $89.71 *$ \\
\hline$(13.50-14.50]$ & 8 & 88.89 & 1 & 11.11 & $60.49 *$ & 111 & 97.37 & 3 & 2.63 & $89.76 *$ \\
\hline$(14.50-15.50]$ & 2 & 100.00 & - & 0.00 & $100.00^{*}$ & 36 & 92.31 & 3 & 7.69 & $71.60 *$ \\
\hline$(15.50-16.50]$ & 7 & 100.00 & - & 0.00 & $100.00 *$ & 23 & 100.00 & - & 0.00 & $100.00 *$ \\
\hline$(16.50-17.50]$ & 2 & 100.00 & - & 0.00 & $100.00 *$ & 25 & 100.00 & - & 0.00 & $100.00 *$ \\
\hline$(17.50-18.50]$ & - & & - & - & - & 9 & 100.00 & - & 0.00 & $100.00 *$ \\
\hline$(18.50-19.50]$ & - & & - & - & - & 6 & 100.00 & - & 0.00 & $100.00 *$ \\
\hline$(19.50-20.50]$ & - & & - & - & - & 1 & 100.00 & - & 0.00 & $100.00 *$ \\
\hline Total & 642 & 39.17 & 997 & 60.83 & $4.69 *$ & 2,452 & 48.73 & 2,582 & 51.27 & 0.07 \\
\hline
\end{tabular}

Table 3. Parameters of the linear regressions resulting from the logarithmic transformation of the weight-length relationship of females and males of Oligosarcus paranensis at Fiú and Mourão Reservoirs, Paraná State, Brazil. $\mathrm{n}=$ number of specimens, $a=$ intercept, $b=$ regression coefficient, $\mathrm{R}^{2}=$ coefficient of determination, $\mathrm{SE}=$ standard error of $b, \mathrm{~F}=\mathrm{F}$ statistic.

Tabela 3. Parâmetros da regressão linear resultante da transformação logarítmica da relação peso-comprimento de fêmeas e machos de Oligosarcus paranensis nos reservatórios de Fiú e Mourão, estado do Paraná, Brasil. $\mathrm{n}=$ número de indivíduos, $a=$ intercepto, $b=$ coeficiente de regressão, $\mathrm{R}^{2}=$ coeficiente de determinação, $\mathrm{SE}=$ erro padrão de $b, \mathrm{~F}=$ estatística $\mathrm{F}$.

\begin{tabular}{ccccc}
\hline \multirow{2}{*}{ Parameter } & \multicolumn{2}{c}{ Fiú } & \multicolumn{2}{c}{ Mourão } \\
\cline { 2 - 5 } & Females & Males & Females & Males \\
\hline $\mathrm{n}$ & 642 & 997 & 2452 & 2582 \\
$a$ & -4.22 & -3.91 & -3.86 & -3.99 \\
$b$ & 3.13 & 3.00 & 2.97 & 3.05 \\
$\mathrm{R}^{2}$ & 0.97 & 0.95 & 0.97 & 0.93 \\
$\mathrm{SE}$ & 0.02 & 0.03 & 0.01 & 0.02 \\
$\mathrm{~F}$ & 17.71 & 17,31 & 84,12 & 33,36 \\
\hline
\end{tabular}

energy to be directed towards growth (in weight and length) as opposed to important requirements such as maintenance and reproduction (King 1995). Among these forces, the increase in population density is a factor that reduces food availability and frequently leads to premature gonad maturation, resulting in a progressive reduction of specimen's growth which can reach the extreme condition of stunting (Wootton 1999). The cannibalism observed at Fiú may also indicate increased population density of O. paranensis, since this behavior commonly acts as an abundance regulator (Nikolsky 1978, Folkvord 1997). Thus, the shorter length of $O$. paranensis at Fiú could be related to a comparatively higher density in that reservoir.

The classic sex ratio in fish is 1:1 (Wootton 1999), however, it can vary considerably among species and populations of the same species in different environments (Nikolsky 1978), as it was observed in the population of Fiú (prevalence of males; 1.6:1.0) and Mourão (1:1). These results also differed from those found by Nunes \& Hartz (2006), who reported the predominance of females in the populations of the congeners $O$. jenynsii and $O$. robustus at Fortaleza lagoon, State of Rio Grande do Sul, Brazil. Vazzoler (1996) commented that distinct environmental conditions (particularly food supply) would be reflected in distinct rates of mortality and/or growth for females and males, resulting in variations, both in the sex ratio among the different length classes and for the population as a whole. On the other hand, the greater length achieved by females, as well as the prevalence of that sex in the classes with greater length for both reservoirs, suggested that this could be a conservative trait of the species. This attribute has an adaptive character in fish, as greater body length can allow a larger number of eggs to be carried, or even to produce larger eggs, which would stand a better chance of larval survival (King 1995).

The different values for regression coefficient $(b)$ for females and males of the same population was consistent with reports on the variation of this parameter for the same species as a function of age, sex, seasonality and/or environmental conditions (Bagenal \& 

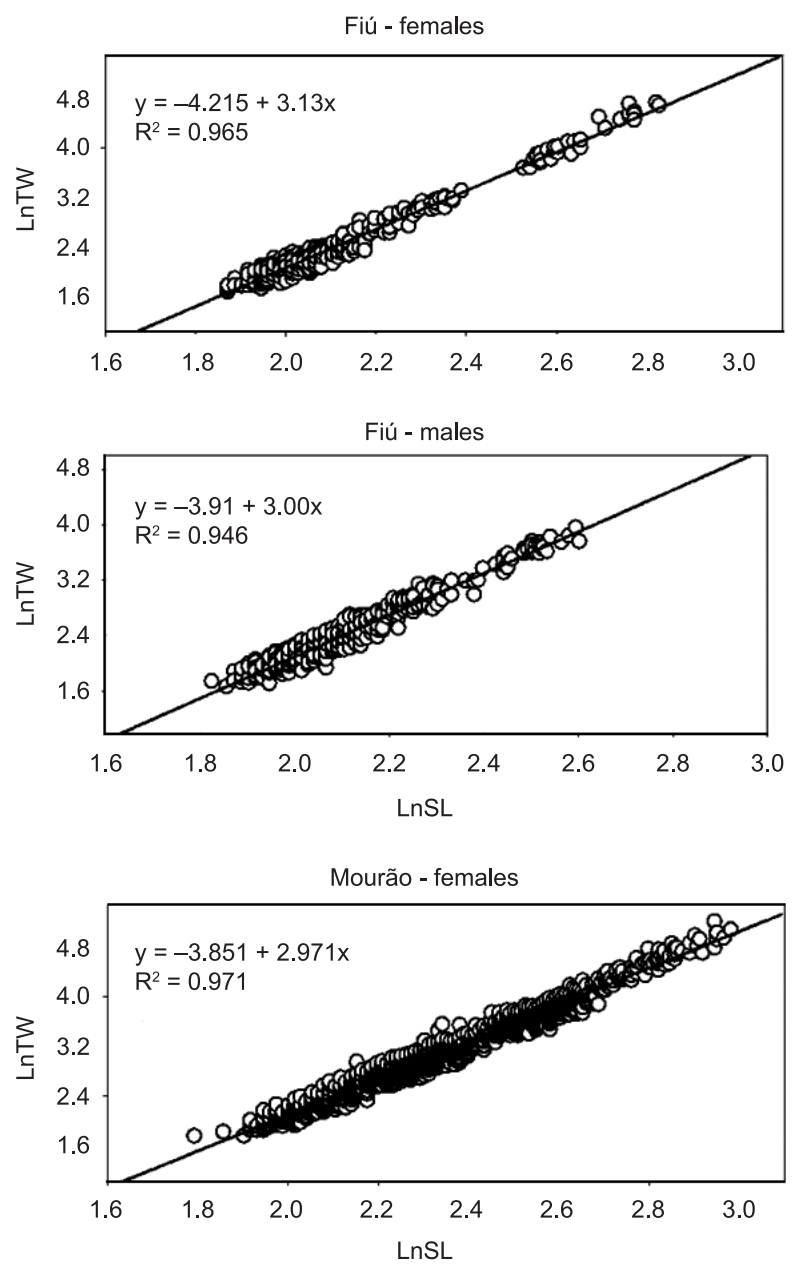

Mourão - males

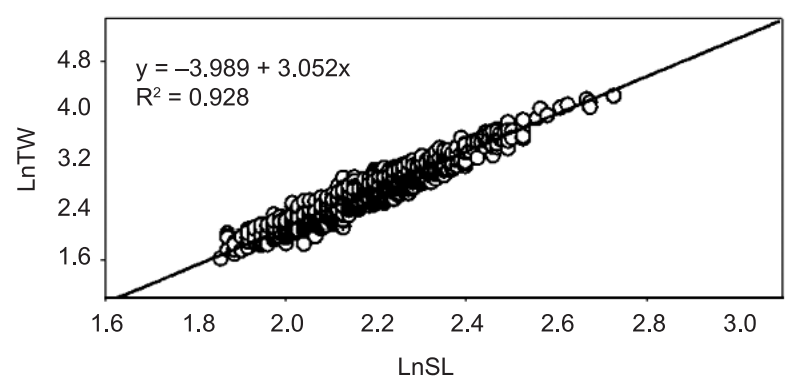

Figure 3. Logarithmic transformation of the weight-length relationship of females and males of Oligosarcus paranensis at Fiú and Mourão Reservoirs, Paraná State, Brazil. LnSL = natural logarithm of standard length, LnTW = natural logarithm of total weight.

Figura 3. Transformação logarítmica da relação peso-comprimento de fêmeas e machos de Oligosarcus paranensis nos reservatórios de Fiú e Mourão, estado do Paraná Brasil. LnSL = logaritmo natural do tamanho padrão, LnTW= logaritmo natural do peso total.

Tesch 1978, Goulart 1994, Godinho 1997, Peck et al. 2005, Nunes $\&$ Hartz 2006). The proposed limit values usually vary between 2.5 and 4.0 according to Pope \& Kruse (2007) or between 2.0 and 4.0 according to Bagenal \& Tesch (1978). However, for the majority of fish populations $b$ is close to 3.0 (Ney 1993), as it was observed for the presented data. With regard to the predominance of allometry among the studied groups, it is not possible to infer whether this is a pattern for the species, as information regarding this parameter for other $O$. paranensis population is not available for comparison.

Concerning condition, it is a generic term employed in reference to the well-being, health, strength, nutritional or energy status of animals (Jakob et al. 1996, Schulte-Hostedde et al. 2005, Stevenson \& Woods Junior 2006). No matter which is the concept established by the author, by measuring this parameter it is assumed that the heavier specimens of a given size are in better condition (Jakob et al. 1996, Schulte-Hostedde et al. 2005, Pope \& Kruse 2007). Thus, it is expected that a fish in better condition will show higher rates of growth, reproductive potential and survival when subjected to environmental pressures compared to another specimen in worst condition (Jakob et al. 1996, Sutton et al. 2000, Pope \& Kruse 2007), due to the positive energy budget that can be allocated to growth and reproduction (Wootton 1999). Although there is scarce information about food resources available in the studied reservoirs, fishes were pointed out by Winemiller (1989) as efficient environmental samplers. Thereby, the best condition found for Mourão population, particularly the fact that this condition was maintained among the most abundant length classes of both sexes, supports the hypothesis that food restriction is a relevant modulating factor of the $O$. paranensis population at Fiú.

The information available on the diet of Oligosarcus species, such as O. hepsetus (Deus \& Petrere Junior 2003, Araújo et al. 2005, Botelho et al. 2007), O. jenynsii (Nunes \& Hartz 2006), O. longirostris (Gealh \& Hahn 1998, Loureiro-Crippa \& Hahn 2006), O. pintoi (Meschiatti 1995, Castro \& Casatti 1997), O. planaltinae (Luz-Agostinho et al. 2006) and O. robustus (Nunes \& Hartz 2006) characterized the prevalence of piscivory, with the feeding spectrum including an expressive variety of aquatic and/or terrestrial invertebrates, especially insects and decapods. The composition of the diet of $O$. paranensis in both studied reservoirs was similar to the feeding pattern of the above mentioned congeners, with fishes featuring as the main consumed resource. However, the inclusion of fruits/seeds by the female population at Mourão was uncommon, which evidenced the trophic opportunism of these specimens, as it was a food resource classified as abundant by Abelha (2001) in this reservoir. The unusual representative presence of plant matter in the diet of carnivores is related to the limited ability of their digestive tract to efficiently process hard-to-digest materials, such as cellulose and lignin (Okeyo 1989, Gerking 1994). However, O. paranensis at Mourão consumed mainly seeds that were considerably fragmented and rich in starch, indicating the digestive viability of this carbohydrate and its consequent use as an energetic food resource. Seeds were also consumed seasonally in large amounts by the piscivorous pimelodid Rhamdia quelen in stream environments (Deus \& Petrere Junior 2003), which reinforced the assumption of viability of this plant food as an alternative nutrient source, even for carnivores. It should be noted that possible explanations for this females behavior in Mourão demand investigations (i.e., experimental and stable isotope analyzes) that go beyond the scope of this work. It's worth to emphasize the consumption of the exotic species T. rendalli and M. salmoides in Mourão. This behavior highlighted the predatory activity of $O$. paranensis as a factor regulating the invaders population growth.

The relatively different proportion of the resources composing the diet of females and males (predominance of characins fish intake by females and males at Fiú and the intense predation of cichlids by females and small characids by males at Mourão) suggested resource partition by sex. The use of this tactic is advantageous to reduce or even to avoid competitive interactions, which tend to be accentuated 
Table 4. Result of the Slope Homogeneity, ANCOVA and Separate Slope Model tests applied on the data resulting from the logarithmic transformation of the weight-length relationship of Oligosarcus paranensis at Fiú and Mourão Reservoirs, Paraná State, Brazil. The ANCOVA and Separate Slope Model tested differences in the condiction between $O$. paranensis studied populations and among standard length classes of two sexes in both reservoirs. $F=\mathrm{F}$ statistic, $p=p$ statistic $(\alpha=0.05)$.

Tabela 4. Resultado da homogeneidade de retas, ANCOVA e do Modelo de Inclinação Separada aplicado sobre os dados resultantes da transformação logarítmica da relação peso-comprimento de Oligosarcus paranensis para os reservatórios de Fiú e Mourão, estado do Paraná, Brasil. A ANCOVA e o Modelo de Inclinação Separada testaram diferenças na condição entre as populações de $O$. paranensis e entre as classes de comprimento dos dois sexos em ambos os reservatórios. $F=$ estatística $\mathrm{F} ; p=$ probabilidade $(\alpha=0,05)$.

\begin{tabular}{|c|c|c|c|c|c|c|}
\hline \multirow[t]{2}{*}{ Factors/Statistic } & \multicolumn{2}{|c|}{ Homogeneity of slopes } & \multicolumn{2}{|c|}{ ANCOVA } & \multicolumn{2}{|c|}{ Separate Slope Model } \\
\hline & $F$ & $p$ & $F$ & $p$ & $F$ & $p$ \\
\hline Between populations & 36.00 & $<0.01$ & - & - & 43.63 & $<0.001$ \\
\hline \multicolumn{7}{|c|}{ Female standard length class } \\
\hline$(6.50-7.50]$ & 0.17 & 0.68 & 4.60 & 0.03 & - & - \\
\hline$(7.50-8.50]$ & 9.45 & $<0.01$ & - & - & 8.95 & $<0.01$ \\
\hline$(8.50-9.50]$ & 13.54 & $<0.01$ & - & - & 13.98 & $<0.01$ \\
\hline$(9.50-10.50]$ & 0.01 & 0.97 & 4.22 & 0.04 & - & - \\
\hline \multicolumn{7}{|c|}{ Male standard length class } \\
\hline$(6.50-7.50]$ & 4.76 & 0.03 & - & - & 4.85 & 0.03 \\
\hline$(7.50-8.50]$ & 1.49 & 0.22 & 15.70 & $<0.01$ & - & - \\
\hline$(8.50-9.50]$ & 7.46 & $<0.01$ & - & - & 7.55 & $<0.01$ \\
\hline$(9.50-10.50]$ & 2.11 & 0.15 & 2.89 & 0.09 & - & - \\
\hline
\end{tabular}

Table 5. Composition of the diet of Oligosarcus paranensis, expressed in volume percentage (\%V), at Fiú and Mourão Reservoirs, Paraná State, Brazil.

Tabela 5. Composição da dieta de Oligosarcus paranensis, expressa em porcentagem de volume (\%V), para os reservatórios de Fiú e Mourão, estado do Paraná, Brasil.

\begin{tabular}{|c|c|c|c|c|}
\hline \multirow[t]{2}{*}{ Food resource } & \multicolumn{2}{|c|}{ Fiú $(\% \mathrm{~V})$} & \multicolumn{2}{|c|}{ Mourão (\%V) } \\
\hline & Females & Males & Females & Males \\
\hline \multicolumn{5}{|c|}{ Plant Matter } \\
\hline Fruits/seedsAngiospermae & - & 0.008 & 21.911 & 2.986 \\
\hline Leaf/steam/root Angiospermae & 0.134 & 0.626 & 0.719 & 0.010 \\
\hline Subtotal & 0.134 & 0.633 & 22.630 & 2.995 \\
\hline \multicolumn{5}{|c|}{ Invertebrates } \\
\hline \multicolumn{5}{|l|}{ Aquatic Insects } \\
\hline Diptera (larvae e pupae) & 0.006 & 0.073 & 0.082 & 0.042 \\
\hline Ceratopogonidae (larvae e pupae) & 0.016 & 0.010 & 0.021 & 0.028 \\
\hline Chaoboridae (larvae e pupae) & 0.523 & 3.211 & 0.765 & 1.567 \\
\hline Chironomidae (larvae e pupae) & 0.073 & 0.441 & 0.204 & 0.319 \\
\hline Simulidae (larvae) & - & - & 0.000 & 0.002 \\
\hline Collembola & - & 0.001 & 0.001 & 0.000 \\
\hline Coleoptera (larvae) & - & 0.031 & 0.233 & 0.003 \\
\hline Ephemeroptera (nymph) & 0.568 & 1.104 & 1.047 & 1.830 \\
\hline Hemiptera & 0.000 & 0.000 & 0.035 & 0.218 \\
\hline Megaloptera (larvae) & 0.151 & 1.314 & 0.000 & - \\
\hline Odonata (nymph) & 0.074 & 1.113 & 2.128 & 0.049 \\
\hline Trichoptera (larvae) & 0.028 & 1.221 & - & - \\
\hline Coleoptera (larvae) & 0.308 & 4.400 & - & - \\
\hline \multicolumn{5}{|l|}{ Other Aquatic Invertebrates } \\
\hline Cladocera & 0.004 & 0.533 & 0.010 & 0.728 \\
\hline Copepoda & 0.033 & 0.016 & 0.617 & 5.363 \\
\hline Hydracarina & 0.229 & 1.094 & 0.001 & 0.000 \\
\hline
\end{tabular}


Tabela 5. Continued...

\begin{tabular}{|c|c|c|c|c|}
\hline \multirow[t]{2}{*}{ Food resource } & \multicolumn{2}{|c|}{ Fiú (\%V) } & \multicolumn{2}{|c|}{ Mourão (\%V) } \\
\hline & Females & Males & Females & Males \\
\hline Nematoda & 0.000 & 0.002 & 0.012 & 0.000 \\
\hline Oligochaeta & 0.000 & 0.618 & - & - \\
\hline Ostracoda & 0.006 & 0.443 & 0.000 & 0.001 \\
\hline Testacea & 0.001 & 0.000 & - & - \\
\hline \multicolumn{5}{|l|}{ Terrestrial Insects } \\
\hline Coleoptera & 0.000 & 0.000 & 2.884 & 1.289 \\
\hline Diptera & 0.001 & 0.021 & 0.133 & 0.192 \\
\hline Ephemeroptera & 0.519 & 0.000 & 0.074 & 0.749 \\
\hline Hemiptera & 0.060 & 0.274 & 0.304 & 0.897 \\
\hline Homoptera & 0.000 & 0.143 & 0.015 & 0.003 \\
\hline Hymenoptera & 0.036 & 0.435 & 1.398 & 0.810 \\
\hline Isoptera & 0.000 & 0.000 & 2.224 & 1.977 \\
\hline Lepidoptera & 0.074 & 0.106 & 0.457 & 0.771 \\
\hline Orthoptera & 0.062 & 0.000 & 1.549 & 1.176 \\
\hline Thysanoptera & 0.000 & 0.002 & 0.000 & 0.000 \\
\hline Trichoptera & 0.005 & 0.000 & 0.016 & 0.060 \\
\hline Rests of insects & 0.136 & 1.055 & 0.203 & 0.323 \\
\hline \multicolumn{5}{|c|}{ Other Terrestrial Invertebrates } \\
\hline Aranae & - & - & 0.356 & 0.019 \\
\hline Subtotal & 2.913 & 17.661 & 14.770 & 18.416 \\
\hline \multicolumn{5}{|c|}{ Fishes } \\
\hline Characidae & 17.814 & 6.657 & 0.929 & 0.000 \\
\hline Small characins & 35.107 & 19.019 & - & - \\
\hline Astyanax spp. & 0.496 & 20.921 & - & 77.613 \\
\hline Bryconamericus iheringi & 11.909 & 21.777 & - & - \\
\hline Oligosarcus paranensis & 28.086 & 0.856 & - & - \\
\hline Cichlidae & - & 1.902 & 28.622 & - \\
\hline Crenicichla sp. & - & 1.902 & - & - \\
\hline Tilapia rendalli & - & - & 16.383 & - \\
\hline Micropterus salmoides & - & - & 0.232 & 0.582 \\
\hline Synbranchus sp. & - & - & 2.322 & - \\
\hline Hoplias malabaricus & 0.000 & 0.209 & - & - \\
\hline Fish scale & 1.551 & 0.198 & 0.431 & 0.020 \\
\hline Rests of fish & 1.948 & 7.750 & 11.891 & 0.044 \\
\hline Subtotal & 96.911 & 81.192 & 60.811 & 78.259 \\
\hline \multicolumn{5}{|c|}{ Other } \\
\hline Detritus/sediment & 0.042 & 0.514 & 1.789 & 0.330 \\
\hline \multicolumn{5}{|l|}{ Algae } \\
\hline Bacillariophyceae & $<0.001$ & - & $<0.001$ & - \\
\hline Chlorophyceae & $<0.001$ & - & - & - \\
\hline Subtotal & 0.042 & 0.514 & 1.789 & 0.330 \\
\hline
\end{tabular}

due to the intraspecific similarity in ecological requirements of the specimens (Pianka 2000).

The diets among distinct length classes of piscivores are frequently influenced by ontogeny, which implies in differences in energy requirements, morphological limitations (especially mouth gap) and in foraging ability (prey detection, pursuit and manipulation), resulting in a positive relationship between prey size and predator (Gerking 1994, Abelha et al. 2001). Therefore, a gradual 

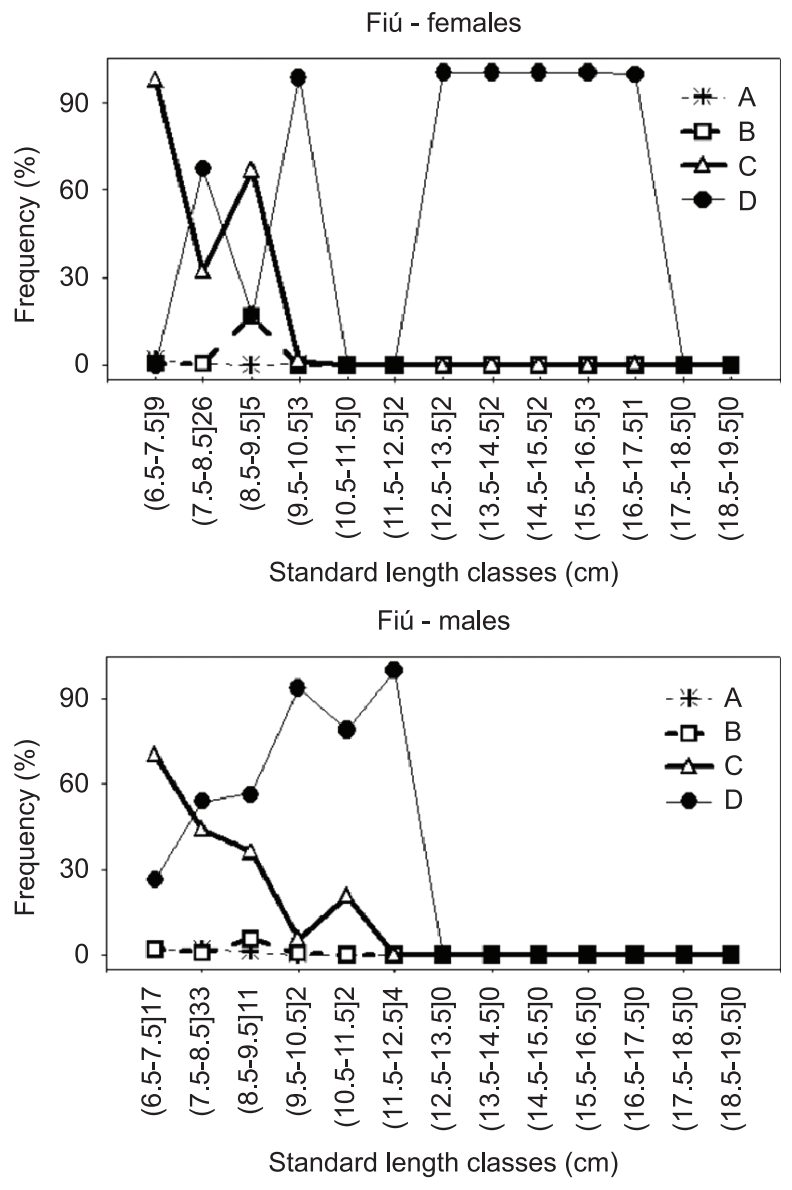

Figure 4. Frequency of food resources consumed among standard length classes (cm) of Oligosarcus paranensis at Fiú Reservoir, Paraná State, Brazil. Values located after class intervals indicate the number of stomachs analyzed per class. Legend: $\mathrm{A}=$ other; $\mathrm{B}=$ plant matter; $\mathrm{C}=$ invertebrates; $\mathrm{D}=$ fishes.

Figura 4. Frequência dos recursos alimentares consumidos entre as classes de comprimento padrão $(\mathrm{cm})$ de Oligosarcus paranensis no reservatório de Fiú, estado do Paraná, Brasil. Valores localizados depois dos intervalos de classe indicam o número de estômagos analisados por classe. Legenda: A = outro; $\mathrm{B}=$ vegetais; $\mathrm{C}=$ invertebrados; $\mathrm{D}=$ peixes.

replacement of the invertivore diet by the piscivore one is expected with the increase in fish length, as was observed for both sexes of O. paranensis at Fiú, and for females at Mourão. This trend was also detected for populations of $O$. hepsetus in reservoir (Araújo et al. 2005) and stream (Botelho et al. 2007) environments, as well as for O. longirostris (Gealh \& Hahn 1998) in reservoirs. Notwithstanding, these considerations contradicted the invertivory observed for the larger length classes of males at Mourão. However, the low stomach sampling of males with standard length equal to or greater than $10.5 \mathrm{~cm}$ does not allow any conclusion.

Considering what was presented here and that predation is a process with a strong impact on the structure and composition of fish communities in reservoirs (Agostinho et al. 1999, Smith \& Petrere Junior 2008), it is reasonable to propose that: (i) although $O$. paranensis populations were abundant in both reservoirs, explored similar resources, the population low condition and prevalence of males in Fiú are factors that can threaten their reproductive success, resulting in the impairment of the detected abundance; (ii) the piscivorous feeding habit suggested a relevant ecological role for $O$. paranensis in maintaining the structure and diversity of the

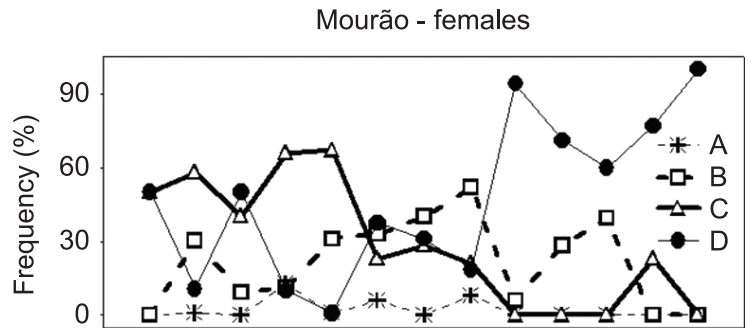

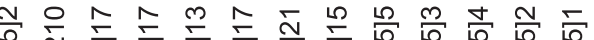

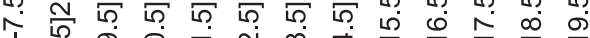
ก ق $N$ 穴

Standard length classes $(\mathrm{cm})$

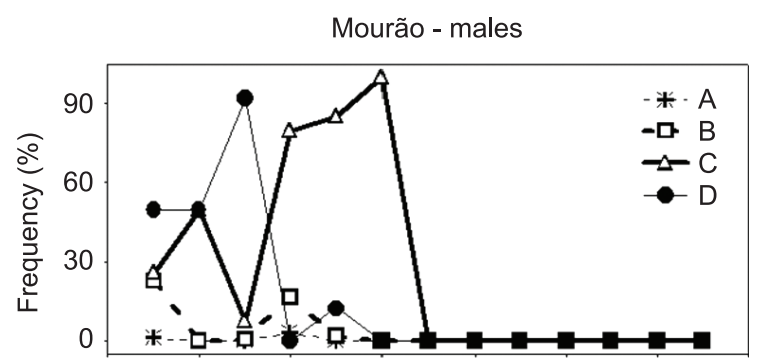

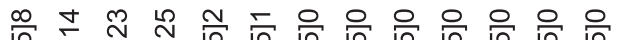
ก. 官 అ Standard length classes $(\mathrm{cm})$

Figure 5. Frequency of food resources consumed among standard length classes $(\mathrm{cm})$ of Oligosarcus paranensis at Mourão Reservoir, Paraná State, Brazil. Values located after class intervals indicate the number of stomachs analyzed per class. Legend: $\mathrm{A}=$ other; $\mathrm{B}=$ plant matter; $\mathrm{C}=$ invertebrates; $\mathrm{D}=$ fishes.

Figura 5. Frequência dos recursos alimentares consumidos entre as classes de comprimento padrão $(\mathrm{cm})$ de Oligosarcus paranensis no reservatório de Mourão, estado do Paraná, Brasil. Valores localizados depois dos intervalos de classe indicam o número de estômagos analisados por classe. Legenda: $\mathrm{A}=$ outro; $\mathrm{B}=$ vegetais $; \mathrm{C}=$ invertebrados $; \mathrm{D}=$ peixes.

ichthyofauna at Fiú and Mourão, so that changes in its abundance will probably result in some form of impact in the properties of the other fish populations that inhabit these reservoirs.

\section{Acknowledgments}

The authors wish to thank PEA/Nupélia-UEM, COPEL and CAPES for the logistical and financial support, Jaime Pereira for developing the map, and Rodrigo Fernandes for statistical assistance.

\section{References}

ABELHA, M.C.F. 2001. Dieta e estrutura trófica da ictiofauna de pequenos reservatórios do estado do Paraná. Dissertação de mestrado, Universidade Estadual de Maringá, Maringá.

ABELHA, M.C.F., AGOSTINHO, A.A. \& GOULART, E. 2001. Plasticidade trófica em peixes de água doce. Acta Sci., Biol. Sci 23(2): 425-434.

AGOstinho, A.A., MIRANDA, L.E., BINI, L.M., GOMES, L.C., THOMAZ, S.M. \& SUZUKI, H.I. 1999. Patterns of colonization in Neotropical reservoirs, and prognoses on aging. In Theoretical reservoir ecology and its applications (J.G. Tundisi \& M. Straškraba, eds.). International Institute of Ecology, São Carlos, p.227-265. 
ARAÚJO, F.G., ANDRADE, C.C., SANTOS, R.N., SANTOS, A.F.G.N. \& SANTOS, L.N. 2005. Spatial and seasonal changes in the diet of Oligosarcus hepsetus (Characiformes, Characidae) in a Brazilian Reservoir, Rio de Janeiro, Brazil. Braz. J. Biol. 65(1):1-8. http://dx.doi. org/10.1590/S1519-69842005000100002

BAGENAL, T.B. \& TESCH, F.W. 1978. Age and growth. In Methods for assessment of fish production in fresh waters (T.B. Bagenal, ed.). Blackwell Scientific Publications, Oxford, p.101-136.

BOTELHO, M.L.L.A., GOMIERO, L.M. \& BRAGA, F.M.S. 2007. Feeding of Oligosarcus hepsetus (Cuvier, 1829) (Characiformes) in the Serra do Mar State Park - Santa Virgínia Unit, São Paulo, Brazil. Braz. J. Biol. 67(4):741-748. http://dx.doi.org/10.1590/S151969842007000400022

CASTRO, A.C.L. 1996. Aspectos ecológicos da comunidade ictiofaunística do reservatório de Barra Bonita, SP. Rev. Bras. Biol. 57(4):665-676.

CASTRO, R.M.C. \& ARCIFA, M.S. 1987. Comunidades de peixes de reservatórios no sul do Brasil. Rev. Bras. Biol. 47(4):493-500.

CASTRO, R.M.C. \& CASATTI, L. 1997. The fish fauna from a small stream of the Upper Paraná River basin, Southeastern Brazil. Ichthyol. Explor. Fres. 7(4):337-352.

DEUS, C.P. \& PETRERE JUNIOR, M. 2003. Seasonal diet shifts of seven fish species in an atlantic rainforest stream in Southeastern Brazil. Braz. J. Biol. 63(4):579:588.

FOLKVORD, A. 1997. Ontogeny of cannibalism in larval and juvenile fishes with special emphasis on Atlantic. In Early life history and recruitment in fish populations (C. Chambers \& E. A. Trippel, eds.). Chapman \& Hall, London, p.251-278. http://dx.doi.org/10.1007/978-94-009-1439-1_9

GARCIA, A.M., HOEINGHAUS, D.J. \& WINEMILLER, K.O. 2007. Isotopic variation of fishes in freshwater and estuarine zones of a large subtropical coastal lagoon. Estuar. Coast Shelf S. 73:399-408. http:// dx.doi.org/10.1016/j.ecss.2007.02.003

GARCÍA-BERTHOU, E. 2001. On the misuse of residuals in ecology: testing regression residuals vs. the analysis of covariance. J. Anim. Ecol. 70:708711. http://dx.doi.org/10.1046/j.1365-2656.2001.00524.x

GEALH, A.M. \& HAHN, N.S. 1998. Alimentação de Oligosarcus longirostris Menezes \& Gèri (Osteichthyes, Acestrorhynchinae) do reservatório de Salto Segredo, Paraná, Brasil. Rev. Bras. Zool. 15(4):985-993.

GERKING, S.D. 1994. Feeding ecology of fish. Academic Press, San Diego.

GODINHO, A.L. 1997. Weight-length relationship and condition of the characiform Triportheus guentheri. Environ. Biol. Fish. 50:319-330. http://dx.doi.org/10.1023/A:1007316028288

GOULART, E. 1994. Estrutura da população, idade, crescimento, reprodução e alimentação de Auchenipterus nuchalis (Spix, 1826) (Osteichthyes, Auchenipteridae) do reservatório de Itaipu-PR. Tese de doutorado, Universidade Federal de São Carlos, São Paulo.

HARTZ, S.M., MARTINS, A. \& BARBIERI, G. 1996. Dinâmica da alimentação de Oligosarcus jenynsii (Gunter, 1864) na lagoa Caconde, Rio Grande do Sul, Brasil (Teleostei, Characidae). Bol. Inst. Pesca 23:21-29.

HELLAWELL, J.M. \& ABEL, R. 1971. A rapid volumetric method for the analysis of the food of fishes. J. Fish Biol. 3:29-37. http://dx.doi. org/10.1111/j.1095-8649.1971.tb05903.x

HYSLOP, E.J. 1980. Stomach contents analysis, a review of methods and their application. J. Fish Biol. 17:411-429. http://dx.doi. org/10.1111/j.1095-8649.1980.tb02775.x

JAKOB, E.M., MARSHALL, S.D. \& UETZ, G.W. 1996. Estimating fitness: a comparison of body condition indices. Oikos 77:61-67. http://dx.doi. org $/ 10.2307 / 3545585$

JÚLIO JUNIOR, H.F., THOMAZ, S.M., AGOSTINHO, A.A. \& LATINI, J.D. 2005. Distribuição e caracterização dos reservatórios. In Biocenose em reservatórios: padrões espaciais e temporais (L. Rodrigues, S.M. Thomaz, A.A. Agostinho \& L.C. Gomes, eds.). Rima Editora, São Carlos, p.1-16.

KING, M. 1995. Fisheries biology, assessment and management. Blackwell Science, Oxford
LOUREIRO-CRIPPA, V.E. \& HAHN, N.S. 2006. Use of food resources by the fish fauna of a small reservoir (rio Jordão, Brazil) before and shortly after its filling. Neotrop. Ichthyol. 4(3):357-362. http://dx.doi.org/10.1590/ S1679-62252006000300007

LUIZ, E.A., GOMES, L.C., AGOSTINHO, A.A. \& BULLA, C.K. 2003. Influência de processos locais e regionais nas assembléias de peixes em reservatórios do Estado do Paraná, Brasil. Acta Sci., Biol. Sci. 25(1):107114.

LUZ-AGOSTINHO, K.D.G., BINI, L.M., FUGI, R., AGOSTINHO, A.A. \& JÚLIO JUNIOR, H.F. 2006. Food spectrum and trophic structure of the ichthyofauna of Corumbá Reservoir, Paraná river basin, Brazil. Neotrop. Ichthyol. 4(1):61-68. http://dx.doi.org/10.1590/S167962252006000100005

MENEZES, N.A. 1988. Implications of the distribution patterns of the species of Oligosarcus (Teleostei, Characidae) from central and Southern South America. In Proceedings of a workshop on Neotropical distribution patterns (P.E. Vanzolini \& W. Ronald Heyer, eds.). Academia Brasileira de Ciências, Rio de Janeiro, p.295-304.

MENEZES, N.A. \& RIBEIRO, A.C. 2010. Oligosarcus jacuiensis (Characiform,es: Characidae), a new species from the Uruguay and Jacuí River basins, southern Brazil. Neotrop. Ichthyol. 8(3):649653. http:// dx.doi.org/10.1590/S1679-62252010000300010

MESCHIATTI, A.J. 1995. Alimentação da comunidade de peixes de uma lagoa marginal do rio Mogi-Guaçu, SP. Acta Limnol. Bras. 7:115-137.

NEY, J.J. 1993. Practical use of biological statistics. In Inland fisheries management in North America (C.C. Kohler \& W.A. Hubert, eds.). American Fisheries Society, Bethesda, p.137-158.

NIKOLSKY, G.V. 1978. The ecology of fishes. T. F. H. Publications, Neptune City.

NUNES, D.M. \& HARTZ, S.M. 2006. Feeding dynamics and ecomorphology of Oligosarcus jenynsii (Gunther, 1864) and Oligosarcus robustus (Menezes, 1969) in the lagoa Fortaleza, Southern Brazil. Braz. J. Biol. 66(1A):121-132. http://dx.doi.org/10.1590/S151969842006000100016

OKEYO, D.O. 1989. Herbivory in freshwater fishes: a review. Isr. J. Aquacult. 41(3):79-97.

PAGIORO, T.A., THOMAZ, S.M. \& ROBERTO, M.C. 2005. Caracterização limnológica abiótica dos reservatórios. In Biocenose em reservatórios: padrões espaciais e temporais (L. Rodrigues, S.M. Thomaz, A.A. Agostinho \& L.C. Gomes, eds.). Rima Editora, São Carlos, p.17-37.

PECK, M.A., CLEMMESEN, C. \& HERRMANN, J.P. 2005. Ontogenetic changes in the allometric scaling of the mass and length relationship in Sprattus sprattus. J. Fish Biol. 66:882-887. http://dx.doi.org/10.1111/ j.0022-1112.2005.00651.x

PIANKA, E.R. 2000. Evolutionary ecology. 6th ed. Benjamin/Cummings, San Francisco.

POPE, K.L. \& KRUSE, C.G. 2007. Condition. In Analysis and Interpretation of Freshwater Fisheries Data (C.S. Guy \& M.L. Brown, eds.). American Fisheries Society, Bethesda, p.423-514.

SCHULTE-HOSTEDDE, A.I., ZINNER, B., MILLAR, J.S. \& HICKLING, G. J. 2005. Restitution of mass-size residuals: validating body condition indices. Ecology 86(1):155-163. http://dx.doi.org/10.1890/04-0232

SMITH, W.S. \& PETRERE JUNIOR, M. 2008. Spatial and temporal patterns and their influence on fish community at Itupararanga Reservoir, Brasil. Rev. Biol. Trop. 56(4):2005-2020. PMid:19419097.

SOSNOVSKY, A. \& QUIRÓS, R. 2009. Effects of fish manipulation on the plankton community in small hypertrophic lakes from the Pampa Plain (Argentina). Limnologica 39:219-229. http://dx.doi.org/10.1016/j. limno.2008.04.004

STATSOFT. 2005. Statistica. Version 7.0. StatSoft Inc., Tulsa.

STEVENSON, R.D. \& WOODS JUNIOR, W.A. 2006. Condition indices for conservation: new uses for envolving tools. Integr. Comp. Biol. 46(6):1169-1190. PMid:21672816. http://dx.doi.org/10.1093/icb/ ic1052 
SUTTON, S.G., BULT, T.P. \& HAEDRICH, R.L. 2000. Relationships among fat weight, body weight, water weight and condition factors in wild atlantic salmon parr. T. Am. Fish. Soc. 129:527-538. http://dx.doi. org/10.1577/1548-8659(2000)129<0527:RAFWBW>2.0.CO;2

TEIXEIRA, R.L. 1989. Aspectos da ecologia de alguns peixes do arroio Bom Jardim, Triunfo, RS. Rev. Bras. Biol. 49(1):183-192.

TERRA, B.F. \& ARAÚJO, F.G. 2011. A preliminary fish assemblage index for a transitional river-reservoir system in southeastern Brazil. Ecol. Indic. 11:874-881. http://dx.doi.org/10.1016/j.ecolind.2010.11.006
VAZZOLER, A.E.A.M. 1996. Biologia da reprodução de peixes teleósteos: teoria e prática. EDUEM, Maringá.

VONO, V., ALVES, C.B.M. \& MAGALHÃES, A.L.B. 1997. A ictiofauna dos cursos d'água tributários do reservatório da futura UHE-Igarapava-Rio Grande. Acta Limnol. Bras. 9:33-43.

WINEMILLER, K.O. 1989. Ontogenetic diet shifts and resource partitioning among piscivorous fishes in the Venezuelan llanos. Environ. Biol. Fish. 26:177-199. http://dx.doi.org/10.1007/BF00004815

WOOTTON, R.J. 1999. Ecology of teleost fishes. Dordrecht, Kluwer Academic Publishers, Dordrecht.

Received 10/08/2011

Revised 13/02/2012

Accepted 26/03/2012 